\title{
An interview with Paul Newman
}

\author{
ALAN S. KAYE
}

\section{Abstract}

In this interview, Paul Newman, Distinguished Professor Emeritus at Indiana University, the world's leading Chadicist and Hausaist, and one of the world's leading linguists specializing in African and Afroasiatic languages and field linguistics, speaks candidly about his long and distinguished career on three continents as linguist, Africanist, and attorney-at-law. Among the topics covered are: (1) his influence in African, Afroasiatic, and general linguistics; (2) his evaluation of the Chomskyan paradigm; (3) his long association with the late Joseph H. Greenberg of Stanford University; (4) his evaluation of the writings of Edward Sapir, Leonard Bloomfield, and Franz Boas; (5) his perceptions of his colleague of many years at Indiana University, the late Thomas A. Sebeok; (6) his views on academic writing and scholarly editing; and (7) his recent formal entrance into the legal field, having graduated with a J.D. degree summa cum laude from Indiana University School of Law in 2003.

\section{Biographical essay}

Paul Newman is an amazing linguist — a linguist's linguist, if you will. Having known him for over three decades, I can personally vouch for the outstanding quality displayed in his multifaceted career as linguist, fieldworker, Africanist, anthropologist, Department Chair, editor and, of fairly recent date, attorney-at-law. Although I recall meeting him first via correspondence in the early 1970s while he was serving in Kano, Nigeria as Director of the Centre for the Study of Nigerian Languages, Chair of the Department of Nigerian Languages, and Professor of African Languages at Abdullahi Bayero College (today's Bayero University), which was then part of the larger Ahmadu Bello University, Zaria, we really got to know one another subsequent to my arrival late in 1973 as a Visiting 
Research Scholar at the Department of Arabic of Abdullahi Bayero College, pursuing a research project of mine on Nigerian Arabic. I soon learned of his polyglottal and other general linguistic talents, in addition to his skill as a very good chess player. We used to play biweekly at my residence on the outskirts of Kano City, which was located next to a hill called Goron Dutse (which in Hausa means 'Bachelor Hill') after a long, hard 'linguistic' day - as if we still needed the mental challenge!

One could speculate that since Newman was born in hot and humid Jacksonville, Florida (on March 7, 1937), he was naturally attracted to the tropical heat of West Africa. This climatic similarity was a far cry from his undergraduate days spent in the city of brotherly love, Philadelphia, where he received his BA degree with honors in Philosophy in 1958 and his MA in Anthropology from the University of Pennsylvania in 1961. Like many other young adults in the early 1960s, Newman was influenced by the election of John F. Kennedy to the White House (which sparked a new wave of idealism 'asking what you could do for your country') to join the US Peace Corps (PC). So, at the age of 24 (in 1961) he went off to Nigeria as a secondary school teacher of mathematics and English in the first wave of PC volunteers going to the Third World. Little did he realize then that the two years he would work there would be the beginning of many more journeys to Africa's most populous nation for research purposes. Northeastern Nigeria was, I suppose, a bit like the old American Wild West in its heyday, since Newman used to ride his horse into the capital of Bornu State, Maiduguri, a fascinating city where one can hear Kanuri (Nilo-Saharan) and Shuwa (Nigerian) Arabic being spoken, in addition to a smattering of other languages, including Hausa. Here I am always reminded of the wonderful picture of horsemen saluting a chief in Magumeri, about 33 miles northwest of Maiduguri (Cohen 1967: 5).

After completing two years of coursework at UCLA for the PhD in linguistics, Newman returned to Nigeria to do fieldwork on Tera (a Chadic language with about 50,000 native speakers), which led to his $\mathrm{PhD}$ dissertation at that university (then considered the top program in African linguistics in the country), awarded in 1967 and published three years later as Newman (1970). The following year saw the publication of two more books: Kirk-Greene and Newman (1971) and his edited special Chadic issue of the Journal of African Languages (Newman 1971). Further fieldwork in Nigeria resulted in another descriptive grammar of a Chadic language, Kanakuru (Newman 1974). During this time frame, general linguists were coming to realize that the Chadic family, which consists of about 150 distinct languages, many of which were (relatively) unknown, was being seriously investigated for the first time. Newman and other fieldworkers, such as his lifelong friend and fellow Chadicist and field 
linguist, Russell Schuh, were rapidly advancing our knowledge of comparative Chadic and thereby also Afroasiatic linguistics, the fields of linguistic typology and language universals, as well as general anthropology and ethnography.

Newman's marriage to fellow linguist Roxana Ma Newman, whom he met at UCLA during his graduate student days, turned out also to net him a vibrant coauthor. I believe it is safe to report that both of them working together launched the first scientific linguistic study of a vast new field, Comparative Chadic (Newman and Ma 1966). This feat is all the more spectacular when one realizes that both of these young scholars were then only graduate students. Together they would go on to produce the standard Modern Hausa-English Dictionary (Newman and Newman 1977a) and coedit Papers in Chadic Linguistics (Newman and Newman 1977b), among other interesting enterprises.

Turning to Newman's professional career per se, he has taught on three continents, making him thereby particularly well qualified, in my view, to comment on international trends in education and academe in general. We have already spoken of his stint as a professor and administrator in Kano, Nigeria. However, before that he landed his first job after receiving his doctorate as an Assistant Professor of Anthropology, later Associate Professor at Yale University's Anthropology Department. He speaks of those fulfilling years in the interview itself, although one can understand the reasons for his decision to leave Ivy League New Haven for Kano, the capital of Hausaland. When the opportunity presented itself three years later, he accepted a professorship and personal Chair (officially bestowed by Her Majesty the Queen) in Europe's finest Department of African Languages at the Rijksuniversiteit te Leiden in the Netherlands. Among his numerous duties there, he somehow managed in 1979 to found and serve as editor-in-chief of what later blossomed into the premier journal in the field of African linguistics - Journal of African Languages and Linguistics $(J A L L)$. He still serves as its consulting editor. All together he spent seven years in Holland, including one year as the head of the department, affording him the opportunity to become very European in his outlook and taste, although he and his wife never became Dutch citizens. Moreover, these Dutch years kindled in him an interest to delve further into Comparative Afroasiatic - a field in which his mentor Greenberg was so pioneering and active (see Kaye and Daniels 1992 for a short history of this discipline formerly known as Comparative Hamito-Semitic). This linguistic specialization consists of his forte, Chadic, along with the related Semitic, Egyptian and Coptic, Berber, Cushitic, and Omotic. Indeed Newman (1980) has stood the test of time and remains the standard work in this métier. 
Newman's academic output, which is still continuing, is truly staggering: author/editor of some 18 books, over 100 articles in a wide variety of refereed journals, and half a dozen ethnomusicological recordings. (He is also a jazz aficionado.) In addition to his own articles and books, he has vast editorial experience, serving as an associate editor for Language and Current Anthropology, and a member of the editorial board of Anthropological Linguistics and Studies in African Linguistics, in addition to the connection with the aforementioned $J A L L$. Due to his involvement with these journals, he developed and refined an interest in the more practical aspects of research and publication - intellectual property and copyright law. It is thus no accident that this area became his specialty as a lawyer. In the spring of 2006, he taught the foundation course in copyright at the Indiana University (IU) School of Law.

After his years in Holland, Newman returned to the United States and in 1983 accepted a position in IU's well-known linguistics department. $\mathrm{He}$ was specifically hired to replace Carleton T. Hodge, who occupied a slot in historical linguistics and whose research area was Afroasiatic linguistics, but with a specialization in ancient Egyptian and Coptic, although Hodge had published on Hausa as well (Hodge 1947, his dissertation done under Zellig S. Harris at the University of Pennsylvania). I remember Hodge being very enthusiastic at his retirement about the opportunity to have Newman replace him.

Newman has won numerous research grants, fellowships, and awards. $\mathrm{He}$ was a Fellow of the Center for Advanced Study in the Behavioral Sciences at Stanford in 1988; NSF grantee (1991-1997), NEH and USDE grantee (1991-1994) for the preparation of his reference grammar of Hausa (Newman 2000); Visiting Research Professor, Indiana-Hamburg Exchange Program (1990); Visiting Research Fellow, Centre for Linguistic Typology, Australian National University, Canberra (1999); and Distinguished Professor at Indiana University since 2002, the highest academic rank bestowed by that university.

Newman's administrative experience in Nigeria and Holland were once again summoned to the challenge when he was asked to serve as a shortterm chair of the linguistics department at IU in 1992. This short-term appointment, in fact, turned into one of six years, and at the end of his term, he presented a smooth-running unit to his successor. Moreover, his administrative prowess is still in evidence in his capacity as Director of the West African Languages Institute, formerly known as the Institute for the Study of Nigerian Languages and Cultures.

I sometimes ask myself if I could embark successfully on a new career in my sixties, as he has done. It staggers the imagination how he could keep up his role as full-time professor, researcher, editor, and attend law 
school full time and receive top grades to boot. One can read all about his new legal career in the body of the interview itself. Let me mention, however, for the record that he pioneered linguistics undergraduate courses at IU in 'Freedom of speech in the United States' and 'Language and law' - two classes that certainly demonstrate that linguistics touches upon so many other disciplines. It is truly a multidisciplinary and an interdisciplinary science.

One of my linguistics students from California State University, Fullerton went on to graduate school at IU and served as his teaching assistant for the first of Newman's aforementioned courses, often telling me what a superb teacher he was. I never had any doubts in this connection and neither did IU, since he received a Teaching Excellence Recognition Award in 1998. As a further tribute to him, a collection of his papers with commentaries has been published in a special congratulatory volume (Jaggar and Wolff 2002).

\section{Interview}

AK: Your publication list is quite impressive and I would think you are very proud of your accomplishments. (I sure know that I would be with a list such as yours). What are your favorite pieces, if I forced you to single out a couple of book-length ventures; also your favorite articles? Why are these your favorites?

PN: I will leave the question of 'favorite' to my article length works; but when it comes to books, I clearly haven't produced anything that approaches my nearly 800-page Hausa reference grammar (2000). This is my magnum opus, the epitome of my life's work, and something that for better or for worse will be my legacy. I have written or edited some eighteen books during my career and, with hindsight, some of them are not so bad, e.g., my historical/comparative study of plurality and pluractionality in Chadic (1990), my translation of and critical essay on Klingenheben's Law (2004), and my book, edited with Martha Ratliff, on linguistic fieldwork (2001). But in the Hausa reference grammar, I delved deeper and more intricately into a subject than I had ever done before. Adding my own perspectives on Hausa, representing the culmination of some forty years of involvement with the language, to a hundred and fifty years of prior scholarship was a huge undertaking. Posterity will decide whether I was successful or not.

Regarding articles, the question of 'favorite' depends on whether I am evaluating (a) the scholarly significance of the piece, (b) the aesthetic/ 
personal creative value, or (c) the impact and contribution on the field. (a) Russell Schuh, whose judgment I respect, is of the opinion that my best article is 'Explaining Hausa feminines' (1979) - and I have to concur. This can be considered best not only in the sense that the findings were significant, but also because it required a real imaginative leap to get to the results. Hausa scholars had known forever that feminine derivation and inflection were accomplished by means of a suffix of the form -iyaa or -uwaa (or a variant thereof), e.g., dóogóo 'tall', dóogúwáa 'tall' (fem.), shéegèe 'bastard', shéegìyáa 'female bastard, bitch.' Lexically feminine nouns with one of these endings were naturally assumed to have derived historically from corresponding masculine nouns, e.g., gàrkúwáa 'shield' (fem.) < *gàrkó (masc.), túfáanìyáa 'mat screen' (fem.) < *túfáanè (masc.), and túnkìáa 'sheep' (fem.) < *túmkì (masc.). The exciting discovery reported in the 'feminines' paper was that the addition of the suffix was not due to derivation or inflection from an earlier masculine form, as always assumed, but rather reflected a process of 'overt characterization,' i.e., the overt morphological marking of nouns that were already feminine, e.g., gàrkúwáa 'shield' (fem.) < *gàrkó (fem. [!]), túnkìyáa 'sheep' (fem) <*túmkì (fem [!]), which, significantly, is the gender that the generic word for sheep always has in Chadic, a distinct root being used for 'ram.' A question that no one had asked before was why so many supposedly masculine nouns, the majority of which referred to inanimates, would change their gender, while other phonologically, morphologically, and semantically similar nouns did not. The answer I provided is that they didn't: these nouns were always intrinsically feminine; they simply changed their morphological shape.

(b) Regarding the pleasure of creation, I am particularly fond of a concise paper that I did entitled 'The origin of Hausa /h/' (1976). Unlike so many long, convoluted articles that one sees in linguistics, I simply stated the question, gave the answer, presented the relevant supporting evidence, said 'tamat' (the end), and stopped. Untypical of my usual painful struggle with writing, I wrote this paper entirely in my head, did a revision and blue-pencil editing of it also in my head, and then wrote it out from beginning to end in one go.

From an emotional, personal point of view, my favorite paper is the little monograph that I did on Greenberg's African linguistic classification (1995). Apart from its intrinsic merits in cutting through all of the misconceptions about Greenberg's work and providing an informed analysis of his approach to classification, the paper is important to me as a tribute to Greenberg, who meant so much to me personally as a mentor, role model, and someone for whom I had the greatest personal affection. 
(c) As far as impact on the field is concern, let me mention two papers, one where my contribution is well known and one where it is not. The first is the comparative Chadic paper that my wife Roxana and I published when we were still graduate students at UCLA (Newman and Ma 1966). Although Greenberg (1950) had already postulated the existence of Chadic as a family, building on the pioneer work of Johannes Lukas, the Doyen of Chadic studies, it is fair to say, without feigned humility, that it was our paper that really launched Chadic linguistics as a distinct and dynamic field of study. Chadic may have been there before, more or less, but we put it on the map.

A paper of mine that has had a lasting impact on the entire field of linguistics is 'Syllable weight as a phonological variable' (1972b). No one nowadays realizes it, but I introduced the term 'syllable weight,' and I was the one who was responsible for the (re-)recognition of the essential role of syllable weight in phonological theory. I say 'rerecognition' because the importance of syllable weight (traditionally described in terms of syllable length) had long been appreciated by Classicists and Semiticists. The obstacle that I had to overcome when I wrote my paper was that not only had syllable weight disappeared from linguistic analysis, the syllable itself had been discarded from the realm of linguistics by the then dominant view of phonology (see Chomsky and Halle 1968). As was my wont, I was never prepared to accept received ideas on authoritarian grounds, and thus as an independent-minded Africanist for whom the syllable was an absolutely indispensable phonological constituent, I was able to present something of significance that the major theoreticians of the day were unable to see because of their theoretical blinders.

AK: What do you think your influence has been over the past few decades in (1) African linguistics, and (2) Chadic and Afroasiatic linguistics?

PN: (1) Apart from what I just mentioned about my introduction of the syllable weight concept and my role as an authority on and interpreter of Greenberg's African classification and the methodology underlying it, Africanists and general phonologists have been particularly appreciative of my various studies of tone, which includes a paper on the Kru language Grebo (1986), one of my few linguistic forays outside of Hausa and Chadic. For example, I have made significant contributions to ongoing discussions about tonal polarity, contour tones, tone displacement, and the nature of 'tone-integrating' affixes. Although I have written much less about ideophones (see, e.g., 1968, 2001), I have contributed fundamental ideas in this area of study, especially the notion that ideophones are not a totally separate class of weird words as often purported, but 
rather, are a category of words that are more or less ideophonic, the degree of their ideophonicity, i.e., how phono-semantically marked they are, varying from language to language and also from class to class or part of speech to part of speech within a language. At a different level, an ongoing contribution of mine to the field of African linguistics, one that hopefully will survive me by many years, was my creation of $J A L L$, the Journal of African Languages and Linguistics, of which I was the founding editor while at Leiden.

(2) It is hard to talk about my role in Chadic linguistics without sounding self-important, which I find uncomfortable. Suffice it to say that I have been involved in and have been a major player in Chadic linguistics throughout my professional career, extending from the 1966 Newman/ Ma paper to the summary overview paper that I published in the Schuh Festschrift (2006). My comparative work has served as a point of reference in the areas of classification and reconstruction, and I have introduced organizing concepts, sometimes with newly coined terminology, that other Chadic scholars (as well as general African linguists) have found useful. These include 'pluractional' verbs, 'intransitive copy pronouns' (ICPs), which are pronominal clitics attached to verbs that match the person/number/gender of the subject, and 'efferential' verb extensions (not to be confused with causatives), which are extensions indicating verbal action emanating from the subject but extending away, either literally or conceptually, e.g., 'pour away' versus 'pour in' or 'teach' versus 'learn.'

Strictly speaking, one should include Hausa in a discussion of Chadic since it is an integral member of the family, but because of its size and long history of linguistic scholarship, common usage sets it apart. My original intention as a graduate student and beginning scholar was to focus on small Chadic languages and leave Hausa to the acknowledged experts on the language, most notably F. W. Parsons in London and Claude Gouffé in Paris. I used Hausa as the medium of communication through which I did my field research, but for me it was simply a tool and not an object of study in its own right. I was drawn into Hausa as a proponent of the then disputed but now fully accepted view that Hausa is indeed a Chadic language. I also was drawn into Hausa as someone who, by means of comparative evidence, was able to explain anomalies in Hausa that had stumped the experts. This approach was reflected in the title of an early paper of mine, 'Study Kanakuru, understand Hausa' (1972a). Gradually, however, I devoted more and more time to Hausa, and after three years in Kano, where I was involved in Hausa projects and spoke Hausa on a daily basis, I was hooked. From that point on, more and more of my efforts went into Hausa as opposed to individual Chadic languages or comparative Chadic, eventually culminating in my 
Yale Reference Grammar. I will never command a depth of knowledge of Hausa anywhere close to that of Parsons, but with his passing a dozen years ago, I suppose that people now look to me as a leading expert on the language.

My contribution to Afroasiatic linguistics has been more limited, but I think of some use. Essentially I have dealt with the relationship between Chadic and Afroasiatic from two different perspectives. First, I have been a steadfast and uncompromising proponent of the view that Chadic is indeed a constituent member of the Afroasiatic phylum (Newman 1980), an issue that is - or at least I would hope is - now fully settled. Second, I have tried to get across the idea that Chadic reconstruction, whether lexical, phonological, or morphological, has to be grounded in Chadic per se and should not be contaminated by preconceived ideas drawn from Afroasiatic or Semitic such as the irrational quest for triliteral (= three-consonantal) roots whether justified on the basis of Chadic evidence or not, or the insistence that words in Chadic languages must all begin with a consonant (including an invented glottal stop in the absence of anything else) when true vowel-initial words are commonplace in Chadic and almost certainly existed in Proto-Chadic.

AK: Can you tell us whether there are some pieces (reviews, etc.) which you regret having published? There are a few linguists who have confided to me that they regret a few items they wrote in their youth? I wonder if you have any regrets at all?

PN: I presume that you are referring to my review from some twenty years back (1989) of Mann and Dalby's Thesaurus of African Languages, a work that I trashed unmercifully. Although the review created hard feelings, I have no regrets: the book got what it deserved. When I teach students about writing book reviews, I stress that they should never be cute and that they should avoid humor - it quickly dates a piece and the attempted humor can easily fall flat. (This, by the way, holds equally for articles.) I violated both of those rules in my review of the Thesaurus, which, nevertheless, or because of my acerbic approach, was probably the most effective piece of writing in my career.

There is another paper that I do not regret having published, but in this case, I do regret the personal and professional fallout. In the late 1970s, I gave a talk in Paris, at which the important Chadicist Herrmann Jungraithmayr was present, in which I demonstrated that his widely publicized model of the historical role of apophony in Chadic didn't hold up under scrutiny (see Newman 1977). Jungraithmayr was professionally humiliated by the talk whereupon I became public enemy number one in his 
eyes for the next couple of decades. This effectively cut off all productive scholarly exchange between us and it poisoned the air as far as communication among other Chadic scholars and students was concerned. With the passage of years, the bitterness gradually eroded and the Chadic Iron Curtain eventually crumbled of its own accord; but Chadic studies would have been much more fun and more energetic if the Newman/Jungraithmayr rupture had not occurred.

Getting back to your question, my main regret is not so much with papers that I have written as with ones that I never got around to writing, of which there are too many to mention. Let me comment on three. First, based on some original research that I did on Krio, I came to the conclusion that, contrary to received knowledge, Krio is not a tone language. I intended to publish it with the title 'Krio: A pitch accent system that comes close to being tonal but didn't quite make it' to honor Jim McCawley (see 1970); but, I never finished it although I have no idea why not.

Second, even though there is no shortage of papers on lexicostatistics and glottochronological dating, I wanted to write a no-holds-barred paper showing that the idea is rubbish and that the manner in which it has been accorded linguistic respectability, even by people who are critical of it, has been scientifically scandalous. Swadesh's idea was that even though languages change at very different rates from one another and at different times - something that he knew full well and which everyone else also knows (or ought to know) - a minute part of language is impervious to everything going on around it and changes at a constant rate in a clocklike manner. This proposal was brilliant because it ran against the grain. The problem is that the idea is wrong and had to be wrong given what we know about language as a functionally organic, interactive system. That's $\mathrm{OK}$ : even first-rate scholars make mistakes. What is not OK - which for me is the scientifically scandalous part - is for linguists (and pre-historians) to have adopted the idea and put it to use without having ever subjected it to scientific scrutiny and independent verification. Shocking from a scientific point of view is that the fact that the Swadesh basic word lists and judgments on which he drew his conclusions were not published at the time and, as far as I am aware, have never been published. The English 100 -word and 200-word glosses are, of course, available, but the crucial lists with the words filled in and scored for the dozen or so test languages have never been made publicly available, but rather their existence and accuracy have simply been accepted on faith. The adoption of glottochronological dating was wishful thinking - all linguists would love to have a reliable dating scheme - but that doesn't justify employing unproved techniques and presenting unsubstantiated guesswork as it they 
represented the results of true scholarship. There are people who believe in astrology and others who put faith in the messages in Chinese fortune cookies; in my opinion, the adherents of glottochronological dating belong to the same club.

Third, and on a lighter note, I wish that I had got around to writing up a paper on Chadic gender for which I had a great title, namely 'The sex disaster,' this being a verbal play on an article by Lévi-Strauss entitled 'Le sexe des âstres' (1967). People have always cited the gender of sun and moon in French and German (le soleil [m.] / la lune [f.] versus die Sonne [f] / der Mond [m.]) to show that gender assignment is arbitrary. The point of my inchoate paper drawn from a study of Chadic was that it didn't matter what the gender of sun and moon might be; what was crucial was that they be opposite. It wouldn't have been a brilliant paper, i.e., the linguistic world has survived without it, but I really passed up a catchy title.

AK: Following up your mention of the journal $J A L L$ that you created and edited, do you regret not accepting the editorship of Language that was offered to you many years ago? In general, how do you view editing and editorial duties? Is the referee system just and fair?

PN: Actually, although I was a finalist for the Language position, it was not in fact offered to me, which, with hindsight, is fortunate. I had editorial know-how and experience and, having wide-ranging interests, I knew a lot of people in linguistics, both being plusses for the editorship; nevertheless, I was kidding myself about my suitability for the Language job. The main problem was that my knowledge of linguistic theory was inadequate and to the extent that I did understand it, I didn't like it and, even worse, had serious doubts about the scholarly value of the enterprise. I wasn't quite as disillusioned about linguistics then as I am now - I no longer read articles in Language, only book reviews — but I lacked the deep commitment to the discipline necessary to hold such an important and central role in the field, especially when one is talking about a journal that is the official organ of our main professional society, the Linguistic Society of America (LSA).

The reason why I was attracted to the Language position, other than unabashed professional ambition and egotism - always bad reasons for a scholar to do anything - was because I appreciate the importance of academic editing and personally enjoy it. The average scholar doesn't realize what a critically valuable service editors provide, whether editors of journals or book editors, nor do they have any idea of the difference between good and bad editors and the invaluable contribution that the 
former provide. Here I can tip my hat to you, just limiting myself to your impressive phonology volume (Kaye 1997). The result is that editing is usually a thankless task without professional rewards, with the exception of a few prestigious positions such as being editor of Language or of an undertaking of monumental scope such as the Current Trends series that my former colleague Tom Sebeok edited.

People think of editing as a single task, but it actually encompasses a bundle of disparate activities. Some editors are better at some of these tasks than at others and enjoy (or dislike) the different tasks in different degrees. Take the two major editing jobs, both of which appeal to me and which I am reasonably adept at, namely the selective/evaluative function and the critical supportive/suggestive function. One essential job of an editor is deciding which papers to accept (or elicit, in the case of a volume of invited papers). This requires good judgment and intuition, expansive knowledge of who possible referees are and how to evaluate their comments, the ability to make hard choices without agonizing about it, uncompromising academic integrity, and the courage of one's convictions. After a while, I felt that I could read a paper on any subject in linguistics, no matter how technical or specialized, and determine with 95 percent accuracy whether the paper was worth publishing or not. If I really didn't like a paper, that is to say that under no circumstances would I publish it in a journal with my name on it as editor, I wouldn't even send it out for review and waste the time of my referees or associate editors.

The other task is providing helpful feedback to authors - especially of accepted papers - to enable them to improve their papers. I'm not referring to stylistic copy-editing, although this can be extremely valuable, but rather observations and suggestions about the substance of the paper and how the presentation can be made more coherent and effective. I found that even when I was dealing with a topic about which I knew very little, I could sense weaknesses in a paper, notice non-fit between general statements and the data presented, and spot various other, often quite subtle, internal contradictions. My skill was being able to help authors write their papers better even though it might not have been the way that I myself would have done such a paper. In short, I viewed this type of editing as being in effect a master teacher.

One aspect of editing that I hadn't anticipated was the discovery of how irresponsible, inconsiderate, and even downright rude some of our colleagues can be. Let me share an amusing incident with you from the time that I was editor of $J A L L$. Someone - whom we will leave nameless, of course - submitted a paper that went on for some 80 pages. I informed the person that the paper was much too long, and he replied, 'I 
am much too busy to work on the paper now, but feel free to go ahead and cut it however you think necessary.' Whereupon, I went to the paper cutter and lopped off $2 \frac{1}{2}$ inches from the right and left and 3 inches from the bottom, let the blade fall where it may. Fortunately, someone stopped me from mailing the amputated paper back to the author or I would have made an enemy for life.

The last part of your question implies that you think that the referee system ought to be fair. That's not what it's about. Selection involves professional judgment, intellectual perspective, and academic taste and thus by its nature cannot truly be fair, even if personal bias were eliminated as I always tried as best as I could. My contention was and is that the only real protection for authors is a multiplicity of journals, i.e., alternative outlets. If my decision as editor was 'wrong,' then the paper ought to find a home in some other journal. In fact, I sometimes saw papers that I had rejected appear in other journals; but in only a few cases can I remember feeling that the paper wasn't so terrible and that I could have accepted it without embarrassment.

Getting back to refereeing, what this is really about is ensuring that a paper that gets published in a respectable journal (or book collection) is academically sound. In other words, referees are an essential part of the gatekeeper function of journals. To me, a major problem with unrefereed self-publishing on the web is that there is too much junk out there and there is no way for the unsuspecting reader to separate the gilt from the dross. Although, as I mentioned, I would routinely reject papers on my own recognizance, I would never accept a paper without sending it out to referees, who ideally were people who knew that area of linguistics better than I did. And even when the referees didn't save me the embarrassment of publishing a paper that shouldn't be, which happened in a few cases - e.g., pointing out that the author had already published exactly the same paper elsewhere - they invariably made useful observations. For example, referees typically pointed out relevant citations that the author had overlooked, and they often caught mistakes of fact or suggested additional examples that strengthened the author's argument. In addition, referees often helped authors by identifying really significant contributions of a paper that the authors themselves had failed to foreground and develop properly. Finally, in the cases of papers that had something to say but needed to be reworked and rewritten, some referees went beyond the call of duty and provided an editorial mentor function. In sum, is the referee system perfect? No, some referees turn out to be incompetent and self-serving and annoyingly slow. But in most cases, more often than disappointed authors who are trying to find someone to blame realize, referees do a good, conscientious job. Besides, what is the alternative? 
AK: I would imagine that you are a very hard-working individual and extremely disciplined to have written as much as you have. Can you pass on some tips to those of us who have the desire to write more just how you have managed to do so all these years? Does writing come easy for you?

PN: Writing for me has always been a painful activity. It was only when I accepted this reality and came to terms with the fact that I would never write as quickly and effortlessly as some incredibly productive scholars whom I know and envy that I was able to come up with my own modus operandi. As I explain to graduate students, the key is to have a system. Different people have different personalities and different intellectual styles and thus there is no one-size-fits-all method of writing, but you have to have a system. Waiting for inspiration or for a free moment when one doesn't have other demands is a recipe for failure. The essential ingredient in my approach is time. If I am going to write a 20-page paper, I have to accept the fact that this is going to take me a certain number of hours, let's say 25 (or it could be 20 or 30 or 40 depending on the topic). Other people may write easier and faster, but that is irrelevant: what matters is the realistic time projection for me. This means that I can't kid myself into thinking that I can knock out the paper in an afternoon when it's really going to take a lot longer than that. But the psychologically positive recompense is that I know that if and when I put in the $+/-25$ hours, the paper will in fact be done.

Having determined that one is going to need 25 hours, the next thing is to ensure that one devotes the hours to the writing project and that these are real hours, by which I mean concentrated hours without interruption. On the first matter, a good system is to have set writing hours that appear on one's work calendar. I haven't always done this, but when I was Chair of the linguistics department, I set aside fixed writing hours on fixed days and before long the administrative assistant and secretaries in the department understood that I wasn't to be bothered then. On the second point, it is essential that one treat writing time as inviolate and just as important as classroom time. None of us would allow ourselves to be interrupted in a classroom by a phone call or email or colleague who needed a ride to pick up her car at the shop: for me the rules are the same for my writing hours. Universities are schizoid when it comes to faculty research and writing. On the one hand they insist that research is an essential part of one's activities, and that this is the primary basis on which one is evaluated for tenure and promotion. On the other, there are various ways in which research is viewed as the faculty members own 'personal' work to be done in spare time when 'important' things such as 
classroom teaching, office hours, committee meetings, etc., are out of the way.

Once one has time set aside, one needs to use it productively, which, for people like me for whom writing is a struggle, means avoiding procrastination. A tip here is put off typing in the enumerable examples with wordby-word glosses while one is in the creative writing stage. All one really needs is a mnemonic or memo indicating what example or data set goes where. The full examples, the typing of which is time-consuming busy work that can detract from the much more difficult job of composing the paper itself, can easily be inserted later. Similarly, don't stop to type in full references. I insist that my students use a good bibliography program and there is absolutely no excuse for scholars not to do so. Finally, let me offer a couple of practical tips, one a procedural strategy and one a little trick. In writing a paper, don't start from the beginning. The place to start is with the descriptive, substantively meaty section(s) of the paper or chapter(s) of the book. When this is done, one can write the conclusion, which summarizes the findings and discusses their significance, and when that is done the beginning of the piece will flow and almost write itself. By contrast, starting at the very beginning with a blank page staring you in the face is an invitation to writer's block. I am 'technologically challenged' and old-fashioned - for example, I still like to use a fountain pen rather than a ball point - but when it comes to writing and being able to start in the middle and move things around at will, computers are the best invention since sliced bread.

A little trick I learned, which particularly applies to long papers, monographs, and books, is not to stop one's writing session at the end of a section or chapter. That makes getting started the next day that much harder, whereas if you jump right in where you left off, the next day is going to start off easier and be more productive. Ladefoged even suggested stopping in the middle of a sentence (see Kaye 2006: 330). Whereas most people could consider that carrying the idea to an extreme, I in fact have tried it at times and found that for me it worked.

Finally, the fundamental issue when it comes to writing is having something to say! Many people have trouble getting an article written because when all is said and done they don't have anything worth writing about. If you've done research - which most theoretical linguists don't do and therefore have learned something of interest to share, writing it up really isn't all that hard if one approaches the task sensibly and with a modicum of self-discipline.

AK: The name Noam Chomsky is almost synonymous with linguistics today. What is your opinion about him and the Chomskyan paradigm? 
What are your reactions to his work and his influence on the field and related ones? How do you feel about his perspective that linguistics is, in essence, part of psychology?

PN: Who am I to evaluate Noam Chomsky? I am a person known to have opinions about everything, to the point one could say of being excessively opinionated, but this one I will pass on. However, if pressed, I would simply say that for me, Chomsky has to be thought of as a Freud and not a Darwin, and let readers draw their own conclusions therefrom.

This comparison with Freud, by the way, has nothing to do with the notion of linguistics being a part of psychology, which is just plain silly reductionism. One could equally argue that psychology is in essence part of biology, which in turn is nothing but chemistry, which itself boils down to the physics of atoms. There are lots of questions about language where the answer is in fact going to come from an understanding of psychology or physiology or the structure and workings of the brain. Why is speech tempo similar in all languages (assuming that this is true)? What are 'words'? How do bilinguals store and access their two languages? Is a Bantu noun class system with some fifteen classes the same as a French two-gender system but with more 'genders,' as is often assumed, or are they psycholinguistically truly different, which is my hunch? Does syntax exist independent of meaning, a fundamental postulate of Chomskyan linguistics? And even the basic question of what is language may ultimately be answered by recourse to the evolution of human psychology. But I would contend that there are still innumerable questions about language structure, similarities and differences among languages, and historical evolution that can be studied profitably by linguistics as an autonomous discipline.

For example, the explanation for why the plural of the Hausa word for 'heart' zúucìáa (where $c$ orthographically represents English $<\mathrm{ch}>$ ) is $z \dot{u}$ kàatáa lies in autonomous morphology, phonology, and language history, and not in cognitive psychology. To save your readers the trouble and expense of buying my grammar, here's the quick solution. The plural is an internal -aa- plural using a $C_{1} V-C_{2} a a C_{3}-a a$ template with an associated High-Low-High tone pattern; cf., sírdii 'saddle', pl. síràadáa. This plural form zúkàatáa is built in a perfectly regular manner if one constructs it not on the singular as now found, but rather on the historically underlying root $* z u ́ k t i ̀$, i.e., in reality, it is not the plural that is strange, as would appear on first sight, but rather the singular. The current singular form has resulted from three processes, one morphological and two phonological. The morphological process was the addition of the feminative -ìyáa suffix, which is dropped in the plural. Then, starting with the root 
shape *zúktì, the word underwent weakening of syllable-final / $/$ to $/ \mathrm{u} /$ in accordance with a rule known as Klingenheben's Law, and palatalization of $/ \mathrm{t} /$ to $/ \mathrm{c} /$ before the front vowel in accordance with a still semiautomatic rule, and voilà, one has zúucìáa. Note that modern-day native speakers do not know any of this and thus they normally employ an alternative much simpler plural, namely zúucíóoyii with the productive -ooCii (all high tone) suffix (where $\mathrm{C}$ is a copy of the stem-final consonant).

AK: How has linguistics changed since you first started teaching? Would you characterize these changes as more or less the same changes that have characterized other fields in the humanities or social sciences?

PN: To me the most depressing thing about linguistics is how much it has not changed? People are still wasting their time on endless Talmudic discussions of this theory or that rather than doing 'normal science,' to use Kuhn's term (a term that for me is positive contrary to the absurd misconceptions of the theoretical elite in linguistics). I went to a job talk not too many years back, and I felt that I was in a time warp. It was exactly the same vacuous talk that I had heard time and time again 25 years earlier, and here was some bright and energetic recent $\mathrm{PhD}$ repeating the same stuff. The examples were possibly different and the formalism and in-theory may have changed, but fundamentally it was the same old tried-and-true tune. The problem is that the powers that be in the field still don't understand that if linguistics is worth its salt, then it has to be thought of and adhered to as 'the scientific study of language,' whereas they still hold to the totally misguided and sterile notion that linguistics is 'the intellectual study of linguistic theory.'

The only saving grace is that the satellite subbranches of linguistics seem to be thriving. The basic core of the field is rotten through and through - I cringe when I think of energetic young graduate students being subjected to bucket loads of phonological and syntactic theory they get in their first and second year classes - but people on the periphery are doing interesting work, whether in psycholinguistics, speech disorders, language and human evolution, or language and law, not to mention phonetics and historical linguistics, two pseudo core areas that have been spared the worst of theoretical vacuity and trendiness.

AK: Where is linguistics heading in the next decade or two? What will be the relationship between the formal linguists and those linguists who have other interests, such as linguistic anthropologists or philologically inclined linguists? 
PN: As the great philosopher Yogi Berra said, 'It's hard to predict, especially about the future,' but since formal linguistics — what I would prefer to call 'scholastic linguistics' - has been going around in circles for the past decade or two, like a one-oared row-boat with a fixed rudder, there is no reason to expect that linguistics will be anywhere except where it is right now, i.e., it's heading nowhere. To give an example, when one considers that Optimality Theory, which, given its intellectual emptiness, should have had a half-life of 10 minutes, has survived and plagued the field for 10 years, there unfortunately is no basis for optimism that things will improve in the future. Most likely the relationship between the scholastic theoreticians and the real linguists will continue as it is now. That is, people who do real research on real languages or real aspects of human language as such will continue to do their own thing, for which they will occasionally be recognized, while the people who are enamored with linguistic theory for its own sake will continue to produce empty verbiage for which they will be rewarded by achieving positions of dominance and influence in the linguistics profession and in university linguistics programs. Of course, I am being unkind to my theoretically minded colleagues and am casting aspersions on a field of which I have been a part throughout my professional life, but I suspect that there is more truth to my hyperbole than even I am comfortable admitting.

AK: Have you ever wanted to write an introductory linguistics textbook covering the entire field? If so, what sorts of things would make yours different from those out there?

PN: No, although I am sure that the idea of writing a historical textbook must have crossed my mind at some time or other. The problem with the historical linguistic textbooks that I have suffered with the many times that I have taught the subject is that they are not 'teachable fromable,' a failing that they share with most books in linguistics that claim to be textbooks. That is, they invariably represent solid scholarship by excellent historical linguists - people who know a lot more about historical linguistics than I ever will - but they are not competently designed textbooks, if by that one understands a book that makes it easy for teachers to teach and for students to learn. Take, for example, the well-regarded textbooks by Anttila (1972) and Hock (1991). When I teach, I make full use of both of these books as reference works for me as instructor, but I can't use them as is in offering a coherent course. In the first place, they include much too much. For example, Anttila's book includes some 60 (!) references at the end of his chapter on Rule Change. Does he really 
expect students to drop everything and read them? And Hock's book goes on for some 700 pages, far beyond what one could cover in a onesemester course, which is what one has a right to expect from a well thought-out textbook. In the second place, they include too little. A really good and helpful textbook will have well-chosen and adequate exercises for students to do and have study questions at the end of each chapter, which should bear some relation to some number of classroom periods, something that these books don't have. But at least these books contain reliable information and don't irritate me by being cute the way that some of the newer historical textbooks do.

AK: You have seen many linguists come and go over the years literally and metaphorically speaking. In retrospect, who would you rank as the very top during the last half century and why? Also, who have been your favorites for a stimulating read?

PN: Leaving aside Chomsky, whose stature in linguistics and as a public intellectual is so gigantic that it is pointless to talk about him, the three scholars whom I would put at the top are (in unranked alphabetical order), Joe Greenberg, Bill Labov, and Peter Ladefoged.

Joseph Greenberg essentially established the field of modern linguistic typology. Typology, of course, has had a long history in linguistics but, at the time that Greenberg appeared on the scene, it had essentially been discarded from linguistics as being uninteresting and theoretically irrelevant if not linguistically disreputable and suspect. (As you know, in the nineteenth century, typological characteristics, such as the presence or absence or gender or whether languages were inflectional as opposed to isolating, were tied into racial and racist notions of human psychology and intelligence; and in the early twentieth century, typology was misused and abused in historical classifications.) In his work, Greenberg opened up investigation into the principles and methods of historical/genetic classification, and he made enormous substantive contributions, starting with his monumental African linguistic classification, which has stood the test of time, but also including his later and still controversial classifications of Native American and European-Asian languages.

Bill Labov helped create the field of sociolinguistics from the outset and then by insisting on scientific rigor, prevented it from dissolving into a nebulous sociology of language, as is sometimes the case, i.e., linguistics for students who hate linguistics. Labov showed that the ideal language spoken by an ideal speaker-hearer doesn't exist, and that close empirical examination of variation can enlighten us about language structure and language history. 
If Labov demonstrated that the sociolinguistic approach to language could be scientific, Peter Ladefoged demonstrated that scientific laboratory phonetics was a rightful and essential part of general linguistics and had important contributions to make to the development of theoretical constructs in linguistics. Ladefoged also showed that serious phonetics did not have to be done in some well-equipped laboratory in Los Angeles or New Haven or London, but that it was possible to take the lab to the field, which he did on more than one occasion. Whereas many linguists have been content to have meetings at which they could spend hours crying about the loss of endangered languages, Ladefoged packed up his equipment and went out to remote places to document some of these languages before they disappeared. In fact, when he died in London in January, 2006 at the age of 80 , he had just returned from a linguistic field trip to India.

AK: With regard to Greenberg, is it your opinion that his American Indian work will one day become accepted? There are only a handful of specialists today who think he got it right.

PN: Of course his classification will ultimately be accepted - assuming, of course, that it is fundamentally correct. If he is badly off the mark, which I personally doubt, then his American Indian work will properly be rejected and relegated to footnotes as a good (or, more likely, bad) try. Some years down the road, once the personal jealousies and ad hominem attacks are out of the way, the matter will be decided like all real scientific disputes based on the preponderance of the empirical evidence. Right now there is a huge amount of irrelevancy in the rhetoric on both sides. For example, there is the pro-Greenberg argument that since his method was so successful in Africa, that same method applied to Native American languages had to achieve equally good results. The problem here is that Greenberg's method is really a heuristic and not a formal algorithm; moreover, the reliability of his results here also depends on the accuracy of his data and his understanding and handling of them. On the other hand, the attempt by Greenberg's critics to attack his method by denigrating his accomplishments in the African classification is meanspirited revisionist history that is totally false. Even if Greenberg's American Indian classification were to prove to be off the mark, it would not change his enormous accomplishments in the African field some generation earlier. Before leaving the issue of his Native American work, I would like to point out something of importance that is never mentioned by his detractors, who are absolutely obsessed with finding picky mistakes here and there in his work, which is that not even his most severe critics 
have attempted to defend the absurd classifications with $+/-135$ totally separate stocks in the New World that was in place before Greenberg's classification appeared on the scene (see Newman 1993). Greenberg once joked to me that if one had had as many separate stocks and separate migrations into the New World as claimed by Lyle Campbell and others, one would have needed a traffic cop up in the Bering Straits to handle the rush hour traffic.

AK: Can you elaborate on your personal relationship with Greenberg?

PN: If my memory is correct, the first time I met Greenberg was in 1963 by the lions in front of the New York Public Library. I was returning from a two-year Peace Corps stint in northern Nigeria, where I had done a bit of research on a few Chadic languages during my spare time, and since I would be stopping in New York on my way to UCLA to begin my doctoral work, I summoned up the courage to write to Greenberg to ask whether I could meet him for a half an hour, to which he agreed. That was about it, although I seem to remember that I communicated with him occasionally while I was at UCLA. When I really got to know him was four or five years later while I was at Yale. Greenberg, who by then had already moved to Stanford, had a sabbatical year in New York. Hal Conklin, who had been a colleague of Greenberg at Columbia, arranged for him to come to New Haven once a week to give a course. Since I was the most junior person in the department, it fell on me to pick Greenberg up from the train station, just before noon, and bring him to campus. Since the class was not until about 1:30 or 2:00 we ended up having lunch together. As is the norm with the Yale's and Harvard's of the world, the distinguished faculty in anthropology and linguistics tended to be too busy to meet Greenberg, and so I had him essentially to myself for a private tutorial every week for a semester. Greenberg, as I discovered, was erudite, imaginative, inquisitive, quick-witted, and infectiously good-humored. My understanding of language and my conception of linguistics were indelibly shaped by the weekly meetings that we had. He was the epitome of a scholar and a true intellectual whom I professionally admired and looked up to. But more than that, I established a close personal bond with him that lasted for the next three decades, and my impression is that the feeling was mutual.

Although Greenberg was never far from my side intellectually, in reality our face-to-face get-togethers were rare. However, I had the good fortune of spending 1988-1989 at the Center for Advanced Studies in the Behavioral Sciences at Stanford and during that year I took advantage of the opportunity to see Greenberg on a regular basis. That probably 
was also the time when my wife Roxana and I got close to Greenberg's wife Selma, a lovely, warm woman in her own right.

In the spring of 2001, I went out to see Greenberg three weeks before he died of pancreatic cancer. He was physically weak, but he was in good spirits and intellectually remarkably inquisitive, alert, and sharp witted. On his coffee table were not flowers or greeting cards, but the proofs of the second volume of his work on Eurasiatic languages (Greenberg 2002).

AK: How would you evaluate the writings of Edward Sapir, Leonard Bloomfield, and Franz Boas for the contemporary linguistic scene? How much do you think today's $\mathrm{PhD}$ candidates in linguistics have read of them? Would you recommend they be read more or less and why?

PN: Not only have today's PhD students not read any of these people, they have barely heard of them. We here at Indiana do not offer a history of linguistics course and I doubt that we are atypical. As far as our students are concerned - and I am afraid that this is true of linguists in general - linguistics as a field was invented by Noam Chomsky in 1957 by the stroke of a pen and that's the long and short of the matter. Since I have always had a historical bent, I think that this is a huge mistake. The only way to understand where linguistics stands now and the direction in which it going is to appreciate where it came from. This also applies to a proper appreciation of Chomsky himself. To understand the substance of the Chomskyan revolution and the intellectual promise that it offered a promise, alas, gone unfulfilled - one needs to understand the state of pre-Chomskyan post-Bloomfieldian linguistics and the extent to which it was in an extreme naive behaviorist straightjacket and was intellectually bankrupt.

Having said this, I don't know whether it is a good use of students' time to have them read Boas and Bloomfield per se rather than to read good secondary sources about them. Boas now seems dated and Bloomfield is not terribly stimulating in that what he says seems so obviously right. Sapir, on the other hand, is different. Because of his style and his creative and inventive mind, lots of his writings can still be read today with profit and with enjoyment. For example, I would love to see all graduate students in linguistics be assigned Sapir's Language (1921) as required reading in the summer before beginning their graduate work. And for more advanced students interested in language as a key to prehistory, Sapir's 'Time perspective' monograph (1916), written almost a hundred years ago is a gem that, along with his classic paper on the Navaho (1936), is still the best thing available. Finally, to get a glimpse of Sapir 
the artist, I would recommend that one turn from his gems of linguistic scholarship to his cameo essay on rhyme in poetry (1920).

AK: What is the relation of linguistics in the broadest sense to anthropology? The way I see it, linguistics started out in the United States, say around 1900, as being a part of that discipline. Is this still the case? It seems that anthropologists know more about linguistics than vice versa.

PN: For a long time, linguistics had two parallel highways. Descriptive linguistics, which concerned itself with unwritten exotic/'primitive' languages, emerged and developed as a subfield within anthropology, what one could call 'anthropological linguistics.' Historical linguistics, typology, and the synchronic treatment of major world languages were handled in Germanics or Classics or other language departments. To the credit of the LSA, when it was founded way back in 1924, it ignored this institutional division and welcomed linguists of all persuasions whatever the object of their linguistic research might be. With the emergence of linguistics as a discipline with self-standing university departments, pure linguists in anthropology departments became something of an anachronism. (That my first job at Yale was in the anthropology department was a fluke, made possible in part by the fact that I did have an MA in anthropology from a strong program.) However, because of long tradition going back to Franz Boas, it was the case that linguists who worked on American Indian languages (e.g., Floyd Lounsbury) could still find a home in an anthropology department whereas Africanists, for example, who did work of exactly the same type would normally be in a linguistics department or, if that did not exist, a Near Eastern and African Languages Department, as was the case with William Welmers at UCLA. The few old-style American Indian specialists apart, the so-called linguists whom one now finds in anthropology departments tend to be anthropologists who study language in a social/cultural setting and not people working on language structure per se, i.e., these are what one might call linguistic anthropologists rather than anthropological linguists. I agree that linguists nowadays know almost nothing about anthropology, but from my experience, the ignorance is mutual.

AK: You have listened to many a linguistics lecture or talk over the years. Is there one speaker (or perhaps two or three) you can single out for clarity and pizzazz? I always thought the late Kenneth Pike and the late Charles Hockett had marvelous styles of delivery and always had something interesting to say. 
PN: I try not to go to linguistics talks because they invariably bore me, and even worse, I almost never learn anything from them. Bill Labov is an entertaining speaker and always has something interesting to say, but he is a rare exception. At LSA meetings, I intellectually benefit by talking with creative people, such as John Goldsmith and Bill Croft (about linguistics or other intellectual matters, but not just gossip), but I try not to go to talks unless it is to show support for a student or to meet social obligations in the case of an international visitor. The problem with linguistic talks is not that linguists are necessarily more incompetent that people in other fields, but that linguistics does not lend itself to oral presentations. (Marshall McLuhan, whom I'm not sure anyone reads anymore, was absolutely right in emphasizing the importance of the medium of communication in determining the effectiveness of the message.) In linguistics, the interest for me is in the details. Vague, broad talks aimed at a general audience are always vapid, and specialized talks with handouts full of data are impossible to digest and appreciate in the time available. There used to be a system at international conferences of reading papers by title only. I don't know whether this is still in vogue, but those were the papers that I always liked best.

AK: Having studied with Harry Hoijer at UCLA and Mary Haas at Berkeley, I always admired their fieldwork savvy and attention to detail in analysis, both synchronic and diachronic, on many different levels. Another teacher of mine about whom I can express similar sentiments is Berkeley's Murray Emeneau, who recently passed away at the age of 101, another Sapirian. How important is fieldwork today, and as a corollary to this question, how would a Mary Haas or a Murray Emeneau fit in with today's linguists?

PN: To me the most positive development in linguistics in the past decade has been the rediscovery of fieldwork as an important and valued activity in our discipline, something that I have championed over the years. Whether this represents a real change of heart or whether it's just a temporary fad coattailing on the endangered languages movement, I can't say, but one has to be thankful and encouraged. Let me mention two things that dramatize the change. The first is the Linguistic Fieldwork book (2001) that I jointly edited with Martha Ratliff, an expert on Southeast Asian languages at Wayne State University. When I first contacted major linguistics publishers with the idea some ten years ago, none of them were interested: their response was that no one in linguistics was interested in fieldwork and that the book wouldn't sell. The circumstances under which Cambridge University Press agreed to take on the book is 
too long a story to tell here, but the bottom line is that I am extremely grateful to them for their confidence in me and their willingness to publish an economically risky book (for which they have been rewarded with excellent sales). Regarding the general lack of interest in fieldwork, you know first hand that the article that I published on fieldwork and field methods courses back in 1992 appeared in your California Linguistic Notes newsletter rather than in a standard journal such as Language because no journal editor would give it a second thought, the topic being considered too trivial. (Let me thank you here for having had the foresight to publish this piece, which after the fact has been oft cited and well appreciated.) The second objective measure of the change is the establishment of a Chair in Fieldwork for the LSA summer institute named in honor of the late Ken Hale. Until recently it was normal practice not to offer field methods at the institutes even when they were hosted at institutions (which I shall leave unnamed) that purport to value fieldwork highly.

The critical question is not how respected senior linguists such as Mary Haas or Murray Emeneau would fit in, but how young people who define themselves as 'field linguists' are treated in the profession nowadays, and the answer is not well. Linguistics departments are still dominated by people who do phonological or syntactic theory and young field linguists continue to find it hard to get jobs and when they do they find themselves at the bottom of the prestige ladder. Because of funding developments at the US National Science Foundation and the established of the Endangered Languages Center at SOAS in London, young scholars, either pre$\mathrm{PhD}$ or early post- $\mathrm{PhD}$ are being encouraged to do fieldwork and are getting funding to do so. At first sight, this seems terrific, but I fear that we may be doing these people a disservice. We like the idea that they are going to the field to do basic descriptive work, but, speaking only for the Americans, I worry about what kind of job prospects they are going to have when they get done with their field research and write-up.

AK: You have taught at Yale, Ahmadu Bello University in Kano, Nigeria, the University of Leiden, and Indiana University. Why so many moves, and can you tell us something about your experiences in each?

PN: Compared to colleagues like you, who whenever I contact them seem to be either about to go to or have just returned from some distant place, I am by nature an unadventurous stick-in-the-mud who doesn't like to travel. Therefore, I have never thought of myself as someone whose career was characterized by lots of moves. However, it is true that that I have worked at four different places on three different continents, and so one could get the impression that I have moved around a lot. The 
important thing to keep in mind is that none of these were lateral moves, i.e., each experience was professionally and personally different from the others. Let me briefly comment on each of them.

Yale (where I was in the Anthropology Department) was my first academic job. I was hired while I was in Nigeria doing field research for my dissertation, it not being uncommon back then to take up a teaching job before having finished one's PhD. In my case, I didn't mess around: I returned from the field during the summer and immediately set to work writing up my thesis, which I finished before Christmas. (Amusingly, while in Nigeria, I also received an unsolicited offer of a job in the department of African languages at Wisconsin to teach Xhosa, an appointment that would have been a better fit than Yale because of my focus on Africa. I rejected the offer out of hand because I had never been to South Africa and knew nothing about the language. It should have been obvious that Xhosa was a typo for Hausa, but with all kinds of pressures surrounding me at the time - northern Nigeria where I was doing my research was experiencing violent and bloody anti-Igbo riots - I wasn't thinking clearly, and so it was to Yale I went.)

My years at Yale were wonderful. I had supportive colleagues, a great library, and very smart students. In reality, Yale was like one long (ultimately six year) post-doc. I worked closely with (translate as 'studied with') Floyd Lounsbury and Hal Conklin (my first department Chair), two fantastic individuals as well as first-rate scholars, and I also met frequently with Cornelius Osgood (not to be confused with the psychologist Charles Osgood), an expert on material culture of the Arctic and the Far East. (Osgood's account of his early fieldwork in his book Winter [1953] is a literary jewel that field linguists and linguistics students are unfortunately unfamiliar with.) Osgood, the senior member of the anthropology department and I had a professional alternating generation (grandparentgrandchild) relationship. It was by sitting at his footsteps and listening attentively to what he said that I learned what little I know about the functioning of academia and academic institutions.

There were, however, a couple of problems with Yale that eventually lead to my leaving. The first is that I never really sensed that I belonged. I always had the uncomfortable feeling that I was teaching at a place that never would have accepted me as a student. But more important, I didn't feel that I was carrying my weight and contributing anything of importance. I taught introductory linguistics classes to anthropology students who mostly had no interest in linguistics, but when all was said and done, I was a minor figure in the department. I personally was benefiting, but I was giving back little in return, and so when the opportunity came to take on a challenging position in Nigeria, I grabbed it. 
I went to Bayero University, Kano (then Abdullahi Bayero College) to take up the post of Director of a Nigerian languages center, an administrative and research position rather than a teaching position. I was only there for three years (1972-1975), but those were watershed years that became the point of reference for my subsequent career. It was during my time in Kano that I actually became a Hausa specialist, although I never really gave up comparative Chadic. One of our big projects was the preparation of a concise Hausa-English dictionary (Newman and Newman 1977a) aimed at a Nigerian rather than expatriate audience. Through this I greatly increased my knowledge of Hausa and also was introduced to the field of lexicography, something that remained one of my serious interests from that point on.

The Kano years were also important because of the long-lasting professional and personal relationships that I established, with expatriate as well as with Nigerian linguists. I also established a close institutional tie with Bayero University that has remained in place over the ensuing three decades, sometimes manifesting itself in my visits to Kano, sometimes through the Hausa students who came to Indiana to pursue their $\mathrm{PhD}$ degrees with me.

After Kano, I moved to the University of Leiden. Leiden was only supposed to be a brief stay serving as a transition between Nigeria and a planned return to the States, but it ended up lasting some seven years. Unlike at Yale, where I was a peripheral member of an Anthropology Department, at Leiden, I was a core member of a small but active department of African linguistics headed by Jan Voorhoeve. I don't think that it is an exaggeration to say that Leiden at that time had one of the top African linguistics programs in the world, if not the top program. Teaching duties were relatively light and the focus was on research, writing, workshops, colloquia, and other productive activities. It was this forward looking and creative atmosphere that prompted us and allowed us to start the Journal of African Languages and Linguistics at a time when other African linguistics journals were folding.

My wife Roxana and I loved living in Europe. Apart from its own charms - which included bicycling and tulips - Holland was conveniently located so that visits with colleagues in Belgium, France, Germany, and England were commonplace. I don't think that we ever truly felt Dutch, but by the time we left to return to the U.S., we certainly had become European in many senses of the term.

Compared to all of my other positions, which de facto were temporary stays, Indiana University constitutes the one long-term permanent position in my career. I came to Bloomington more than twenty years ago and I am still here [but see postscript below]. Apart from doing my 
expected teaching - field methods and historical linguistics being my regular fare - and keeping up an active program of research and writing, I served for six years as Chair of the linguistics department. I was moderately successful as Chair, which is all that I could hope for given my lack of talents for the job. Because I have no tolerance for incompetence, am incapable of bestowing unearned praise, and do not suffer fools gladly, I inevitably offended colleagues in the department, and because I have an allergic reaction to dishonesty, hypocrisy, and arbitrary authority, my relationship with the Deans and other members of the administration was predictably difficult. Nevertheless, I know that there are students who were accepted into the $\mathrm{PhD}$ program and got their degrees because of me and that many of the members of our diverse and interesting department were hired and got tenure as a result of my efforts. So, I didn't do too badly despite my personality drawbacks. One accomplishment that I am particular proud of was setting up and raising money for a research fund (named in honor of the memory of Fred Householder, one of Indiana's most illustrious linguists) which provides student research support in the $+/-\$ 500$ range almost for the asking.

As with any job, I had good years and bad years at IU, but on the whole the university treated me well, recognized my accomplishments, including naming me to the rank of Distinguished Professor, and made it possible for me to do the African linguistic research that I love.

AK: A longtime colleague of yours at IU, who was a very prolific writer and editor, was Thomas A. Sebeok. How well did you know him? Did you have any occasion to work with him or use any of his work in your own? How was he regarded by administrators, faculty colleagues, and students there?

PN: Physically Tom Sebeok was a man of small stature, but intellectually he was a giant. Apart from his seminal role in the creation of semiotics, Sebeok was a talented and very productive general linguist, who even served as president of the LSA (1975). The term 'Renaissance Man' is overused, but in Sebeok's case, it is apt. He travelled extensively, had friends and acquaintances around the world, read widely, and was knowledgeable on an incredible range of subjects. He was also a wonderfully lively conversationalist. He had colleagues in the university who found him to be insufferable for one reason or another, often having to do with his penchant for self-promotion, but I always enjoyed talking with him and made a point of doing so (the routine being joining him for early 11:30 lunch at his specially reserved table at his regular restaurant of that year). Whether the discussion concerned academic politics, animal 
communication, or a book that Sebeok had just read, I never failed to learn something from him. I can't say that I knew Tom well and since our areas of research didn't overlap I never had occasion to work with him; however, I had great professional respect for him and have very fond memories of the informal times that we did spend together.

When I came to Bloomington in 1983, Sebeok had already established an international reputation; nevertheless, at IU, he was ignored to a great extent. This behavior seems typical of universities, namely having a star in one's midst who is not appreciated in his or her home institution. This is partly related to the fact that most university administrators, who tediously pay lip service to 'excellence,' really prefer faculty who are B+ team players than truly inventive and imaginative professors who may be professionally outspoken, institutionally demanding, or personally idiosyncratic. In the case of other faculty members, the failure to relate to someone of Sebeok's status is undoubtedly due to a certain amount of professional resentment and jealousy.

AK: Can you tell us something about your students over the years and their work?

PN: With a few exceptions, I have been singularly unsuccessful in helping to produce the next generation of linguists, and I have been a total failure when it comes to Chadic apart from Hausa. Remarkably - I suppose - I have not had one American student who has gone on to establish a productive career in academia. My excellent American students Kemp Williams and Charles Morrill have excelled in other careers, the former in the computer world, the latter in the foreign service, but both unfortunately left linguistics to apply their talents elsewhere.

My best two best students, best in the sense of subsequently academically most successful, were Gerrit Dimmendaal, whose thesis on Turkana I directed when I was in Leiden, and Maria Rosa Lloret, whose brilliant thesis on Oromo phonology was done with me at Indiana. Gerrit, who is currently professor at the University of Cologne, has developed into a linguist of wide scope and one of Europe's leading Africanists. Maria Rosa, who has an important professorial position at the University of Barcelona, has managed to keep up her interest in Oromo while developing into a recognized expert on general phonology and Catalan linguistics.

My other PhD students, while not numerous, have also been remarkably good. I am particularly proud of the accomplishments of JinSeong Lee, from Seoul, whose thesis was on ideophonic words in Korean, and, most recently, Manuel Triano-López, from Huelva (near Seville), who studied language attitudes and language policy in Valencia. I have 
had four Hausa-speaking PhD students while at Indiana, all of whom wrote high-quality theses and finished their degrees promptly, something that I insist on with my students. They are Ismail Junaidu (who did Hausa syntax), Sammani Sani (who did Hausa political language), Mustapha Ahmad Isa (who did Hausa morphology), and Ousseina Alidou, recently tenured at Rutgers (who studied language games in Hausa and a half a dozen other languages of Niger).

AK: What were your favorite academically challenging teaching activities over the years and why? I know you developed a stimulating course in linguistics and legal issues. Can you tell us something of that course and how it worked out the times you offered it?

PN: I taught field methods innumerable times and it was always a challenge. I particularly enjoyed it because it gave me the opportunity to work on a wide array of African (and African derived) languages other than languages of the Chadic family that I normally work on. These include languages belonging to other branches of Afroasiatic, namely Oromo (Cushitic), Tigrinya (Ethio-Semitic), and Tamashaq (Berber), but also Ewe, Grebo, and Kisi (Niger-Congo), Nuer (Nilo-Saharan), and Krio (of Sierra Leone) and Sranan (of Surinam), two creole languages. The best for me personally was the class on Grebo because it allowed me to work on a language with four tone levels, something that I had never done before. The worst was Nuer, because neither I nor the students ever succeeded in transcribing it accurately much less figuring out how the language worked. In introductory linguistics classes, we invariably teach unsuspecting naive students that all languages are equally complex and difficult. After my frustrating experience with Nuer, I'm not sure that I believe that!

In addition to having taught Contracts and Copyright Law in the law school, both extremely demanding, I have taught two law-related courses at the undergraduate level. One is a general education course on freedom of speech in the U.S., intended to introduce students to First Amendment principles and practices. This is a timely course in which students always have things to say. The hardest part in teaching such a course has been in suppressing my own political views and biases, which for purposes of the course are irrelevant. The other is a linguistics course on language and law. The content varied each time that I taught it; but the general scope was (a) the nature of legal language, (b) language in a legal setting (e.g., the role of interpreters in the courtroom), (c) 'forensic linguistics,' i.e., linguistic techniques for solving legal disputes (e.g., authorship determination of texts or speaker identification), and (d) laws regarding language 
(e.g., trademark or the English only movement). Ideally, one would want to teach this course to students who already had a reasonable background both in linguistics and in law. In reality, most of the students started out with neither. Nevertheless, I generally was able to cut through the mystery of both fields and thus managed to present a spirited and informative class. Having a number of lively, knowledgeable guest speakers always helped.

I might add that in recent years I have changed my opinion about undergraduates. For a long time I bought into the idea that undergraduate teaching was a chore and that as a senior scholar I had earned the right to teach graduate students. However, I have since come around to the realization that graduate teaching is often tedious and boring and undergraduate teaching is more rewarding. Some undergraduates can be incredibly irresponsible and intellectually unequipped for college, but on the whole if you give them their due, they can be inquisitive, refreshingly skeptical, responsive, and a lot of fun to teach.

AK: Let's go back to your own undergraduate days. Who were your most memorable instructors and what courses stand out so many decades later? Has undergraduate education changed for the better? What do you think about general education requirements and foreign language requirements?

PN: My undergraduate days at the University of Pennsylvania were so long ago I'm not sure what I really remember and what is memory once removed, i.e., recollections of things that I have said or thought that I had remembered on other occasions. Still, for what it's worth, let me mention two professors who taught me as an undergraduate at Penn and who stand out for very different reasons. The first is the great philosopher Nelson Goodman, with whom I took my senior honors seminar. I have no idea now what the seminar was about, and I probably didn't have a much better idea at the time either, but I was absolutely 'blown away' by Goodman's intellect and the incisiveness of his mind. When it came time for the final exam, which was scheduled for two hours, he gave us the questions at 10:00 a.m. and didn't give us the blue books in which to write our answers until over an hour later. As he explained, if people thought more and wrote less, we would have more trees and better scholarship.

The second is someone you wouldn't have heard of, a professor named Bernard Cataldo, who - ironically as things later turned out - was my instructor in a business law course that I took in the Wharton School. What attracted me to him in the class was that his passion was not mundane business law, but rather etymology, language usage, and other 
humanistic interests. As he later told me, he had wanted to major in Latin and become a schoolteacher, but since this was during the depression and Classics in the public schools was on the wane, he feared that he would not be able to get a job and so he switched to law, which seemed more practical.

However, my sharpest memories of Cataldo derive not from business law class but from a university incident (cause celèbre) involving the theater program. As an undergraduate, I was actively involved in the student drama group. Unlike my namesake, I have absolutely no theatrical talent and thus was forbidden by my fellow students from appearing on the stage; but I loved the excitement of the theater and thus became part of it by being involved in policy issues and practical production matters. On one occasion, we students decided that we wanted to put on The Crucible, an incredibly powerful play, if you have never seen it. The faculty adviser vetoed our choice because, in her view, Arthur Miller was a communist and that was that. We, of course, protested vehemently in terms of academic freedom, student rights, etc., and it fell on me to become one of the spokesmen for our group. At first the administration quietly backed the adviser hoping that the matter would go away, but it continued to escalate. At some point, Cataldo was brought in as a mediator, about the only person on campus who was respected by and acceptable to both sides. Eventually he came up with a solution, which, if I remember correctly, was that the play should in fact go on as a university production, but it would be totally under the auspices and direction of the students, without the endorsement or participation by the faculty adviser. In his handling of the matter, Cataldo taught me two things (the second of which I never learned very well). The first was that when it came to fundamental, deeply held beliefs - freedom of expression in our case, patriotism and anti-communism in hers - one needed to have the courage of one's convictions and be willing to stand up for one's principles and stick with them. The other was that one needed to be gracious in victory and not gloat nor gratuitously humiliate your opponent. In Cataldo's view, the cliché taken from sports about being a good loser was misguided; more important in life was learning to be a good winner.

As far as undergraduate education in general is concerned, my views are no better nor no worse than any other laymen speaking from ignorance, i.e., I am offering pure opinion with no particular knowledge to back it up. The students now are obviously worse than they were before, and we know that this is true because it has always been true. I believe it was Socrates who commented on the same thing. But seriously, the real answer is that schools are so varied and students are so varied that it makes no sense to try to come up with an ideal one-size-fits-all 
undergraduate program. What might be ideal for a small highly selective private school such as Swarthmore or Oberlin or Carleton College is not necessarily what would work for a public mega-university such as Ohio State or Texas. What I would say, since you've given me the opportunity, is that we university professors are off the mark when we constantly harp on the need for higher academic standards, something mouthed sanctimoniously by the president of the NCAA, whoever he might be. We have become so enamored with the value of our own trivial classes that we lose sight of the enormous educational value of the university experience and the fact that after four years in such a setting, students are much better off than when they arrived. This is particularly true of college athletes, and particularly true of those with the least academic skills and background, and even more true of those, especially African Americans, who come from socially disadvantaged backgrounds. The notion that these students shouldn't be allowed to play football or basketball because they have no interest in taking, much less passing, my elective course on languages of the world, let's say, is absurd. It may sound crazy, but I would contend that we academics sell the university short when we insist that students whose passion is for other things take our classes and pretend to be interested in them. Most learning in a university takes place outside the classroom, and don't kid yourself, these football and basketball players who leave without graduating undoubtedly learned a huge amount and established lifelong social skills and friendships, all in all an experience equally as valuable as that gained by the middle-class white kid with the four point average who made your teaching of the class so enjoyable to you personally.

AK: Now let me ask you the same question about your graduate school education. Do you think that the system operative at some European universities is better without any formal coursework for the doctorate?

PN: My PhD studies at UCLA are a blur. In fact, I was physically there in Los Angeles for only two years. I did my course work, (barely) passed my reading exams in French and German, took my qualifying exams, and then went off to Nigeria to do dissertation research. When my year of fieldwork was finished, I took up a job at Yale and thus had to write my dissertation in absentia, which I did in five months. This is not to imply that the UCLA years weren't great; they were. I had first-rate teachers, e.g., Peter Ladefoged, Paul Schachter, and Bob Stockwell, just to mention three. William Welmers, who was instrumental in creating the next generation of African linguists, treated me almost as a junior colleague in the department rather than as a student. And last but not least, I was part of a remarkable cohort of students including Vicki Fromkin, who 
was so fabulous, Charles Bird, Gerard Diffloth, Jacqueline Lindenfeld, Tim Shopen, and my future wife (for almost forty years now) Roxana Ma Newman. It all just happened too fast.

Although your question regarding coursework at the graduate level made reference to Europe, let me answer it strictly in the American context. One has to have graduate courses here in the first instance because linguistics is a field where we still accept incoming graduate students with minimal undergraduate background in the subject, something that other fields, e.g., economics or chemistry, would not allow. This goes back to the time when there were so few undergraduate linguistics programs and linguistics graduate students necessarily came from language departments or philosophy or what have you, which in my opinion is not a bad thing. The second reason one wants courses is because there is a body of essential knowledge that all students really ought to have and the most effective way to get this across is through core courses. Finally, since most students coming in are not really ready to commit themselves to one area of specialization or another, the courses give them the opportunity to see where their interests lead them and to meet professors with whom they are intellectually compatible.

Having said this, I feel strongly that American graduate students take too many courses and for too long. I would limit content courses to two years. Any courses in the third year should be skills courses. Apart from field methods, or statistics, or Arabic or Portuguese, let's say, for a student who needed these languages for research purposes, I think that students would benefit from a serious writing course where they were given instruction and practice in the various genres they will need as professional academics, something they definitely do not get by writing term papers in courses or seminars. I don't know where we learn it - and some of our colleagues never do and never have - but, apart from articles, everyone ought to know how to write abstracts, book reviews, book notices, book prospectuses, grant applications, and grant or article evaluations, not to mention letters of recommendation.

By the beginning of the fourth year - at the latest! - graduate students should get working seriously on thesis research and by the end of the fifth year, it should be done. No nonsense and no excuses. I am not sympathetic in the least to students who hang around for six, seven, eight, or more years and I have utter disdain for my irresponsible colleagues who tolerate, and sometimes encourage, such academically and professionally unacceptable conduct on the part of their students.

AK: I know how you feel about the work of the Summer Institute of Linguistics (SIL). Can you summarize your position presently and have 
you changed any aspects of your thoughts on SIL and SIL linguists over the years?

PN: I'm glad that you know how I feel about SIL because I'm not entirely sure that I do. In answering this question, it is probably best if I separate out a discussion of a specific SIL dispute that I was involved in back in 2005 from my more general views about SIL as an organization.

The dispute concerned plans for SIL to host the 37th Annual Conference on African Linguistics (ACAL). Nominally, the meeting was to be put on jointly with the University of Texas at Arlington, but it was perfectly clear that this was SIL's meeting. When the announcement came out, I raised an objection with the ACAL steering committee that it was inappropriate for ACAL, a scholarly group with a very diverse clientele, to take place under the auspices of a Christian missionary organization. By allowing SIL to host ACAL, we were in effect endorsing SIL and implicitly giving a vote of approval to and legitimizing their activities, which we know always have a religious component and religious objectives. To me this was a separation of church and state (in this case church and science) type issue. My feeling was that allowing SIL to 'capture' ACAL for the year was terribly wrong, even if one were an SIL supporter and admired the enormous amount of descriptive work that they had done over the years. When my objections were met with disdain, silence, and inaction, I indicated to the steering committee that I would be embarking on a campaign to publicize what was going on and do my best to oppose the meeting. I sent out hundreds of emails, this in effect becoming a fulltime job for a while, and received innumerable answers in reply, ranging from principled support (most often from colleagues in Europe) to wishywashy fence sitting, to vicious hate mail. Eventually the University of Texas at Arlington, SIL's partner in this endeavor, caved in and shortly thereafter SIL pulled out. Fortunately the University of Oregon, to whom we owe a debt of thanks, stepped forward on short notice and agreed to host the meeting and so further harm was averted. And that is that. However, for the record, I would, like to say that the people at SIL with whom I communicated during the dispute all behaved in a professionally courteous manner and, given the escalating level of bitterness, remained polite and very decent throughout.

As far as SIL itself is concerned, my attitudes are obviously colored by the fact that I am a freethinker, a child of the Enlightenment, if that doesn't sound too pretentious, who is troubled by the seemingly endless negative impact of organized religion on the course of human history. Whereas I respect the right of truly sincere individuals to practice their religion in accordance with their dictates and beliefs, I have little regard for 
missionaries whose goal it is to destroy traditional cultures and impose their favorite brand of Christianity on defenseless, vulnerable peoples. It thus would be easy for me to be totally dismissive of SIL. However, the reality is that in our linguistic world dominated by vacuous theoreticians, it is SIL linguists who have gone out and done the descriptive work that is so essential to linguistics as an intellectually responsible endeavor. In African linguistics, especially in certain regions and with certain language groups, we are terribly dependent on SIL studies for our empirical base. So, while we might disapprove of their religious objectives, we necessarily use their descriptive grammars and articles in our own work. That is our hypocrisy. Theirs is pretending to be a scholarly organization when and this is something that they admit when pushed - they are first and foremost a religious group. They may do credible linguistic work, and they certainly promote and advertise this scholarly activity as a means of gaining access to the terrain, but, in the finally analysis their work is subservient to and used as a cover for their real missionary aims and objectives. All faith-based initiatives are about faith, and it is terribly dishonest for religious organizations (not to mention ambitious and cynical politicians!) to pretend otherwise.

On the subject of SIL hypocrisy, it irritates me to no end that they have infiltrated the endangered languages movement and pretend to be concerned about the problem. If there were a dying language with just three or four octogenarian speakers left due to the fact that the population had converted fully to Islam and was now adopting, let's say Hausa or Swahili or Arabic, SIL as an organization would not fund research on that language because there would be no religious pay-off for them. Individual SIL members might on their own time and on their own money, but SIL as such would not, which to me is telling. Pretense about linguistics and literacy projects, etc., gets them in the door and gets them visas and work clearance, but deep down it's all a cover-up for their real fundamentalist Christian objectives. SIL knows this and the church members who donate money so that SIL linguists can undertake projects in the third world absolutely understand this. (Some 90 percent of SIL's budget comes from Wycliffe Bible Translators, a missionary organization that doesn't pretend to be other than what it is.) It's only naive linguists such as most members of ACAL who have trouble getting the message.

AK: What are you working on now? How is your day structured?

PN: To be honest, I am being drawn simultaneously in a number of different directions and don't have a clear picture as to what exactly I am working on. I recently finished editing a festschrift for my long-time 
colleague and friend Russell Schuh (Newman and Hyman 2006) and I finally completed the manuscript for a new Hausa-English Dictionary (2007), which is intended to be the counterpart to Roxana Ma Newman's English-Hausa Dictionary published by Yale University Press (1990). I have some ideas about a couple of nonlinguistic books that I would like to do, but whether I will ever sit down and really start on them is problematic. One is a how-to book analyzing effective and, I would say, very feasible ways to improve the functioning of universities, covering things such as faculty hiring, promotion and tenure, evaluation of teaching, and ways to ensure that graduate students finish their $\mathrm{PhD}$ promptly. People scoff at this idea because I don't have any particular training or professional know-how that would qualify me to write such a book, but I am absolutely convinced that I can see though the smokescreen of incompetence and inertia in universities and do have workable solutions. It's disconcerting for me to take the awkward position that everyone else in the university is wrong about the way to get things done and that only I understand what are sensible procedures, but that's seems to be the case.

The other potential project is a book treating the tension between copyright law and academic freedom, concerns that have led to the Creative Commons movement (see Lessig 2004). The problem is that the goal of scholarship is the open and free exchange of ideas whereas copyright law is designed to protect commercial interests by tying up intellectual property in knots unless and until someone forks over some money. For example, the big entertainment conglomerates and multinational publishers are using their enormous power to put restrictions on the internet and internet users, whereas one doesn't have to be a high-tech futurist to realize that the web opens up all kinds of possibilities for the creation of virtual libraries and the worldwide sharing of knowledge. Since the law is not about to change for the better, academic journals, scholarly societies, universities, and individual professors need to come up with self-help measures to cut through the copyright shackles. My project idea is to find out what steps are already being taken and to explore what practically speaking could be done to preserve the 'intellectual' in intellectual property. This would be a demanding project, which I fear exceeds my abilities. However, such a book would appear to make more sense than the Fix the University book in that it builds more naturally on my prior teaching, my legal training, my experience as an academic editor, and my long involvement with the ACLU.

In the meantime, while procrastinating on book ideas, I am spending my time almost exclusively on law-related activities. To begin with, I am teaching the basic copyright course in the law school, filling in for someone who is away on sabbatical. Since this is my first time doing the course 
and since the teaching demands in the law school are much greater than in arts and sciences, this is requiring a lot of effort on my part. But it's worth it since it is forcing me to get into the details and intricacies of copyright law. In addition, I am spending a lot of time on civil liberties work. I am a member of the state board of the ACLU of Indiana involved with decision making and policy matters, and I also go up to Indianapolis once a week to do actual work for them on a pro bono basis. The average person thinks of the ACLU in terms of high profile cases of great constitutional significance, but many of the people who contact us for assistance are poor or undereducated individuals whose rights are being trampled on by 'the system' and are powerless to defend themselves. My job, which usually leaves me emotionally drained, is talking on the phone for hours on end with people whom we privileged middleclass academics seldom come into contact with, listening to their problems, and trying to explain to them their legal rights and giving suggestions where else they might go for help if, as is usually the case, the matter is outside of ACLU's domain or competence. It's frustrating work because most of the time I am convinced that I am really not doing the person any good, but who knows? One day a repeat caller gave me an impossibly difficult time about how the ACLU spent its resources defending atheists and criminals and sexual perverts, etc., and wouldn't take up his case. When in a moment of pique I ask, then why do you bother calling us, he replied, 'Because, of all the places I call, you are the only ones who bother to call me back and listen to my problems and take my complaints seriously.'

AK: Am I correct that you have a law degree? When and how did this happen?

PN: I have had an interest in law and have been concerned about and involved in the battle for human rights, civil rights, and civil liberties for as long as I can remember. Nevertheless, I chose to follow a different and ultimately interesting and satisfying career path in academia, and so my interest in law just lay there dormant until half a dozen years ago. After the publication of my Hausa Reference Grammar (Newman 2000) I was suffering from postpartum depression, so to speak, and thus the question naturally came up about what to do next. To tell you the truth, I can't remember exactly what prompted the notion, but the idea came to me to see if I could take some courses in the law school, specifically with regard to First Amendment law and copyright law, two areas that I had a particular interest in. Knowing human nature (or at least my own personal human frailties), I realized that if I was just going to sit in and audit a 
couple of courses, I would never stick with it and I certainly would not do the hard work necessary to get much out of the courses. And so, I decided to take the plunge and try to do the full J.D. degree just like all of the other students. If I had known in advance how demanding, difficult, and time-consuming it would be, I probably wouldn't have started. But I did start and did stick with it, going essentially full-time while continuing to work full-time, and managed to finish with my class in 2003, graduating summa cum laude, if you will permit my lack of modesty. I then crammed for the bar exam, which I passed, and so I am now officially a lawyer qualified to practice in the State of Indiana.

Various people who have some idea of how demanding law school is have asked me how I managed to accomplish the law degree while carrying on with a full load of work, i.e., how was it possible to juggle all of the conflicting demands? I think that my success boiled down to three things: desire/commitment, self-discipline, and effective use of time.

AK: How did you get along with your fellow students and law school professors, some of whom presumably knew you were a famous linguist and Distinguished Professor at IU?

PN: My rule at law school was that the professors should treat me just like any other student. I suspect that this suspension of disbelief was probably easier for me than it was for them, but that was the game plan. (The fact that grading of exams in law school is anonymous - you put a number on your blue book, not your name - must have helped somewhat.) I made a point of not asking them for favors, such as excusing me from class to permit me to give invited lectures abroad, and they made a point of not turning to me when I might have some special linguistic knowledge of relevance to a case. The only time a professor broke the rules was when I was named Distinguished Professor; he couldn't help announcing it to the class as an extraordinary event to be happening to a law school student in his class. The major drawback to this approach was for three years not being able to go out to lunch and socialize with people who for me could have been most interesting colleagues and friends. But that would have blurred the strict roles that I was trying to keep in place.

My fellow students were wonderful and wonderfully accepting. In the first place, I naturally bonded with the non-traditional students, known jocularly as OWLS ('older and wiser law students'), students in the $+/-40$ year old age group who were doing law school for some reason or other with some other significant career experience under their belts. But even the younger students straight out of college accepted me as one of them. I have no idea what they really thought, but on a day-to-day 
basis, they were friendly and included me in their activities, whether it was a study group, partnering for a mock oral argument, or unwinding on Friday afternoon for beer at the local watering hole. Despite the age that appeared on my driving license and the age that I felt after staying up all night to finish a paper, when I was there in the law school, I was their age. Having young friends and a tough new challenge made me feel young, a far cry from how I had felt some five to seven years earlier when I used to go to university sponsored financial planning sessions for soonto-be-retired professors. When I started law school, I thought that that probably signaled the end of my linguistics career. But that has turned out not to be the case. Rather, interestingly, getting the intellectual batteries recharged has sparked my interest in linguistic questions and has stimulated renewed professional activity. Obviously, human biology has its own rules and so I can't expect to keep this pace up forever; but in the interim, my days are crammed full and my mind is running overtime.

[Postscript: Since this interview was completed, Paul Newman, consistent with his ever willingness to accept professional challenges, has taken on a newly created position at the University of Michigan as Intellectual Property Specialist dealing with matters of copyright and scholarly communication.]

\section{References}

Anttila, Raimo (1972). An Introduction to Historical and Comparative Linguistics. New York: Macmillan.

Chomsky, Noam and Halle, Morris (1968). The Sound Pattern of English. New York: Harper and Row.

Cohen, Ronald (1967). The Kanuri of Bornu. New York: Holt, Rinehart, and Winston.

Greenberg, Joseph H. (1950). Studies in African linguistic classification: IV Hamito-Semitic. Southwestern Journal of Anthropology 6, 47-63.

-(2002). Indo-European and Its Closest Relatives: The Eurasiatic Language Family, Vol. 2, Lexicon. Stanford: Stanford University Press.

Hock, Hans Heinrich (1991). Principles of Historical Linguistics, 2nd ed. Berlin and New York: Mouton de Gruyter.

Hodge, Carleton T. (1947). An Outline of Hausa Grammar (= Language dissertation 41). Baltimore, MD: Linguistic Society of America.

Jaggar, Philip J. and Wolff, H. Ekkehard (eds.) (2002). Chadic and Hausa Linguistics: Selected Papers of Paul Newman, with Commentaries. Cologne: Rüdiger Köppe.

Kaye, Alan S. (ed.) (1997). Phonologies of Asia and Africa (Including the Caucasus), 2 vols. Winona Lake, IN: Eisenbrauns.

- (2006). An interview with Peter Ladefoged. Semiotica 158 (1/4), 319-334.

Kaye, Alan S. and Daniels, Peter T. (1992). Comparative Afroasiatic and general genetic linguistics. Word 43, 429-458. 
Kirk-Greene, Anthony and Newman, Paul (1971). West African Travels and Adventures: Two Autobiographical Narratives from Northern Nigeria. New Haven, CT: Yale University Press.

Lessig, Lawrence (2004). Free Culture. New York: Penguin.

Lévi-Strauss, Claude (1967). Le sexe des âstres. In To Honor Roman Jakobson, vol. 2, W. Sidney Allen (ed.), 1163-1171. The Hague: Mouton.

McCawley, James D. (1970). Some tonal systems that come close to being pitch accent systems but don't quite make it. Chicago Linguistic Society 6, 526-532.

Newman, Paul (1968). Ideophones from a syntactic point of view. Journal of West African Languages 5, 107-117.

-(1970). A Grammar of Tera: Transformational Syntax and Texts (= University of California Publications in Linguistics 57). Berkeley and Los Angeles: University of California Press.

- (1972a). Study Kanakuru, understand Hausa. Harsunan Nijeriya 2, 1-13.

- (1972b). Syllable weight as a phonological variable. Studies in African Linguistics 3, 301323.

-(1974). The Kanakuru Language (= West African Language Monographs 9). Leeds: Institute of Modern English Language Studies; University of Leeds and West African Linguistic Society.

-(1976). The origin of Hausa /h/. Studies in African Linguistics, Suppl. no. 6, 165-175.

- (1977). The formation of the imperfective verb stem in Chadic. Afrika und Übersee 60, $178-192$.

- (1979). Explaining Hausa feminines. Studies in African Linguistics 10, 197-226.

-(1980). The Classification of Chadic within Afroasiatic. Leiden: Universitaire Pers Leiden.

- (1986). Contour tones as phonemic primes in Grebo. In The Phonological Representation of Suprasegmentals, K. Bogers, H. van der Hulst, and M. Mous (eds.), 175-193. Dordrecht: Foris.

- (1989). Review of Thesaurus of African Languages: A Classified and Annotated Inventory of the Spoken Languages of Africa by Michael Mann and David Dalby. Journal of African Languages and Linguistics 11, 175-182.

- (1990). Nominal and Verbal Plurality in Chadic. Dordrecht: Foris.

- (1992). Fieldwork and field methods in linguistics. California Linguistic Notes 23 (2), $1-8$.

- (1993). Greenberg's American Indian classification: A report on the controversy. In Historical Linguistics 1991: Papers from the Tenth International Conference on Historical Linguistics, Jaap van Marle (ed.), 229-242. Amsterdam: John Benjamins.

-(1995). On Being Right: Greenberg's African Linguistic Classification and the Methodological Principles which Underlie It. Bloomington: West African Languages Institute.

-(2000). The Hausa Language: An Encyclopedic Reference Grammar. New Haven, CT: Yale University Press.

-(2001). Are ideophones really as weird and extra-systematic as linguists make them out to be? In Ideophones, F. K. E. Voeltz and C. Killian-Hatz (eds.), 251-258. Amsterdam: John Benjamins.

-(2004). Klingenheben's Law in Hausa. Cologne: Rüdiger Köppe.

- (2006). Comparative Chadic revisited. In West African Linguistics: Papers in Honor of Russell G. Schuh, Paul Newman and Larry M. Hyman (eds.), 188-202. Columbus: Ohio State University.

-(2007). A Hausa-English Dictionary. New Haven, CT: Yale University Press.

—(ed.) (1971). Special Chadic issue. Journal of African Languages 10 (1). 
Newman, Paul and Hyman, Larry M. (eds.) (2006). West African Linguistics: Papers in Honor of Russell G. Schuh (= Studies in African Linguistics, Suppl. No. 11). Columbus: Ohio State University.

Newman, Paul and Ma, Roxana (1966). Comparative Chadic: Phonology and lexicon. Journal of African Languages 5, 218-251.

Newman, Paul and Newman, Roxana Ma (1977a). Modern Hausa-English Dictionary. Ibadan and Zaria: Oxford University Press.

Newman, Paul and Newman, Roxana Ma (eds.) (1977b). Papers in Chadic Linguistics. Leiden: Afrika-Studiecentrum.

Newman, Paul and Ratliff, Martha (eds.) (2001). Linguistic Fieldwork. Cambridge: Cambridge University Press.

Newman, Roxana Ma (1990). An English-Hausa Dictionary. New Haven, CT: Yale University Press.

Osgood, Cornelius (1953). Winter. New York: W. W. Norton.

Sapir, Edward (1916). Time perspective in Aboriginal American culture: A study in method. Ottawa: Government Printing Bureau.

- (1920). The heuristic value of rhyme. Queen's Quarterly 394 (27), 309-312.

-(1921). Language: An Introduction to the Study of Speech. New York: Harcourt, Brace, and Company.

-(1936). Internal linguistic evidence suggestive of the northern origin of the Navaho. American Anthropologist 38, 224-235.

Alan S. Kaye (1944-2007) is Professor of Linguistics and Director of the Phonetics Research Laboratory at California State University, Fullerton〈akaye@fullerton.edu〉. His research interests are phonology and morphology, Semitic and Afroasiatic languages, and Arabic dialectology. His major publications include A Dictionary of Nigerian Arabic (1982); Semitic Studies in Honor of Wolf Leslau (1991); and Phonologies of Asia and Africa (1997). Alan Kaye died suddenly of bone cancer on May 31, 2007. 